\title{
FREEDOM OF CONTRACT IN LABOR RELATIONS*
}

\author{
Linert LIREZA**
}

\begin{abstract}
The development of new technologies and recent changes in the economy has made necessary a change of labour relations, to ensure their compatibility with the latest developments. The aim of this article is to present the evolution and characteristics of the labor contract and its effects on the Albanian practice. The theoretical analysis of these contracts is succeeded by the interviews, which intend to introduce the relation of these contracts with the principle of contractual freedom and to highlight several problems that emerge in this legal action. The state mechanisms aiming to guarantee this principle seem weak. Consequently, the article makes several recommendations which will enable the application of this legal action guaranteeing at once the rights of the contractual parties.

Keywords: contracts; labor relations; free will principle; employee
\end{abstract}

DOI: $10.53373 /$ REDS.2021.52.3.028

\section{Introduction}

The right to contract is one of those fundamental rights in our society that is frequently lauded and rightly receives primary credit for the establishment of a functional, market-based economy in which predictability is prized. ${ }^{1}$ This right is so ingrained that whenever we do hear about infringement of the right to contract, it is usually historical, such as limitations on women's right to contract prior to the nineteenth and twentieth centuries or the rights of slaves or indentured servants preceding the twentieth century. ${ }^{2}$ In addition, the supremacy of contract in our society has evolved from solely a mercantile instrument to one that encompasses transactions that are either not commercial or only tangentially so. ${ }^{3}$

The development of economic relations, the emergence of new forms of production, and the strengthening of participants in the market have caused the emergence of new social relations, and as a result, various legal relations have developed. The new legal relations are different regarding their content and legal

\footnotetext{
* Paper presented at the International Conference "The future of labor law after coronavirus" organized on-line by the Association for the Study of Professional Labor Relations on May 13 and 14, 2021.

** Lecturer PhD, Faculty of the Political Sciences and Law, "Aleksandër Moisiu" University, Durrës, Albania.

${ }^{1}$ See generally David N. Mayer, Liberty to Contract: Rediscovering a lost constitutional right 1-10 (2011) (arguing for a return to the "Lochner era" of American constitutional law and the return of the fundamental right to contract)

2 See generally Anthony R. Chase, Race, Culture, and Contract Law: From the Cottonfield to the Courtroom, 28 CONN. L. REv. 1 (1995) (discussing the inability for slaves to contract).

${ }^{3}$ Yale Human Rights and Development Law Journal, Vol. 16 [2013], Iss. 1, Art. 2
} 
form. Freedom of contact is indisputably a basic, established and cardinal principle of the law of contract. The parties to a contract were to be governed by rational selfinterest. Jeremy Bentham and John Stuart Mill with the principle of utilitarianism saw freedom of contract as a means of freeing the individual from the needless restraints imposed upon him, howbeit with the inherent setback being the failure to recognize that freedom of contract without any form of restriction was tantamount to slavery ${ }^{4}$.This absolute utilitarian freedom of contract had weaknesses especially in the domain of labour law.

During the nineteenth and early twentieth century, the theory of absolute freedom of contract led to poor working conditions for most workers in the industrialized western world and countries such as England and the United States of America ${ }^{5}$. Thus, although classical contract law upholds the theory of private autonomy reflected in the parties' freedom to contract, the need for regulation is seen in special contracts such as that of labour. Labour law is shaped by juridical culture, which is different to certain national legal traditions. From the other side, the society is characterized by distinct conceptions of the employment relationship that took shape in different national systems and that reflect variations in economic conditions and legal cultures.

\section{Employer's power according to contractual freedom}

If, in a contractual perspective, the employment contract seems to be an instrument of negotiation between the different parties, we must note that it is also the first principle for determining the work and employment conditions. From this contract, the employee becomes the creditor of the job provision and of the work tasks corresponding to the accepted qualification. In the domain of contract, it means being able to decide freely whether to conclude a contract, with whom and what the contents should be. ${ }^{6}$

The contents of a labour contract describe the nature of work to be carried out and the conditions under which such work is to be done, including the form of wages. There are however express, discretionary terms of the contract, to be decided upon by the parties, as well as obligatory terms imposed by the law, to be respected and complied with.

However, pure freedom of contract cannot be spoken of as far as labour contracts are concerned due to the inherent inequality in bargaining power and the fact that more often the worker is presented with a standard contract. On the contrary, "poor" states put job seekers at a disadvantage when faced with the choice of type of employment and the contents of a labour contract. As a result, it is almost

\footnotetext{
${ }^{4}$ Nicholas S. Wilson, Freedom of Contract and Adhesion Contracts, The International and Comparative Law Quarterly, Vol. 14, No. 1 (Jan., 1965), pp.173

${ }^{5}$ John S. Brubaker, A realistic critique of freedom of contract in labor law negotiations, creating more optimal and just outcomes, 5 Wash.U.Jur.Rev, pp 109

${ }^{6}$ Gabriel Tavits, "Freedom of contract in labour relations", Juridica International IV/1999, 179-188, 180
} 
impossible to use the freedom to negotiate the terms on the part of worker, who might feel obliged to accept whatever offer for reasons of survival

\section{Labor contract on the view of adhesion contract (contracts with standard conditions)}

The contracts are stipulated by the parties and the free will of the parties is reflected in their freedom to choose the type of contract and the other party as well as, to negotiate the terms and conditions of the specific contract. The contracts are the main functioning tool of the economy. Because of this feature, Kessler states that the freedom of contract does not commend itself for moral reasons only; it is also an eminently practical principle. It is the inevitable counterpart of a free enterprise system. ${ }^{7}$ These anomalous contracts are called contracts of adhesion and are characterized by a lack of bargaining power in one of the parties to the agreement and by the fact that they are written entirely by one party and offered on a "take it or leave it" basis to the other. ${ }^{8}$

The first adhesion contracts were utilized in public services like rail services, sea or air transportation, the postal service's processes, etc., in which the contracting party is in a superior legal position due to the market conditions, compared to the economically weaker contractual party. Currently, this kind of contract is spread massively in banking, construction, transport etc. Other new types of contracts that meet the conditions to be considered as adhesion contracts are: leasing contracts, banking contracts, factoring and especially the electronic contracts through internet.

For the first time, the contracts with standard conditions, called: the standardized mass contracts ${ }^{9}$, are presented in legal economic relations at the end of XIX century (1901). Usually these contracts are addressed to the consumers.

The contract stipulation manner functions on the basis of soft law, because it is regulated by the business practices as long as there are no specific provisions in the respective laws, regarding the way the parties should approach each-other, or should negotiate the clauses, even if they are limited. The contract is concluded on the basis of the business' experience aiming to finish the procedure as fast as possible and to predict the future circumstances in relation to the client. ${ }^{10}$

The contract with standard conditions is characterized by unconditional total proposal's bid, which one of the contracting parties will propose publicly to an

\footnotetext{
${ }^{7}$ Pound, Liberty of Contract (1909), Yale L.J.; Williston, Freedom of Contract (1921), Cornel.L L. Q. 365; Hamilton, Freedom of Contract, ENcvc. Soc. Scr. 450, cited by: Kessler, Friedrich, Contracts of Adhesion-Some Thoughts About Freedom of Contract (1943). Faculty Scholarship Series. Paper 2731,.

${ }^{8}$ Duncan, N. Adhesion Contracts: A Twentieth Century Problem for a Nineteenth Century Code. 34 La. L. Rev.1974

${ }^{9}$ Kessler, Fr. Contracts of Adhesion-Some Thoughts About Freedom of Contract. Faculty Scholarship Series., 1943, Pa. 2731

${ }^{10}$ Hetemi.M, Detyrimet dhe kontratat,Tirane,Luarasi, 1998, p. 29
} 
unspecified number of people without giving recipients the opportunity to participate in determining the content of the contract.

In connection to what was said above, other features of contract forms are derived, such as; unconditional acceptance of the offer; the public offer; inability of the nominees to influence the substance of the contract and the economic superiority of the bidder.

The main characteristic of adhesion contracts is that "the contract content is absolutely the same as the offer content. The parties skip the negotiating process in these contracts. The bidder can bind the contract if only he/she fully accepts the offer. Therefore, the person who wishes to stipulate the contract with the bidder, to achieve certain goals, can only accept the offer "en bloc".

Thus, employers find it convenient to present certain standard form contracts to employees for signature. The contract, which frequently contains many conditions, which are favourable to the employer, is presented for acceptance en bloc and is not open to discussion." 11

The desperate worker has no choice in this case than to accept the contract as proposed or to reject it. The only remedy to the worker can be found in State regulation through legislation and collective bargaining.

\section{The inability of the offer recipient to change the content in public labor sector}

The contract is an agreement between two legally equal parties, in order to create and change legal relationships between them. In the adhesion contracts, the modus operandi is different. In the standard contracts the recipient of the offer can accept or reject the offer, without defining the conditions for this acceptance. Contractual clauses are compiled unilaterally and the other party has the option to accept or reject "en bloc."

Every legal or physical person may accept the offer in its entirety and in any case the content of the offer becomes the contract content, for example the economic actors dealing with transportation of goods, first declare publicly and unify the conditions of the contract on transportation, fee etc. and consequently, any natural or legal person has the opportunity to adhere to this general offer and thus to bind the contract for transportation. ${ }^{12}$ The economic impetus for the development of contracts of adhesion is the need for uniformity of contract terms that deal with the same products or services of the company in mass production and distribution and to help reduce possible risks facing the company under the terms of a contract. ${ }^{13}$

\footnotetext{
${ }_{11}^{11}$ Amos And Walton, Introduction to French Law, 2 nd Edn. (1963) P.152., Ibid, note 7,

${ }^{12}$ Dauti. N. Roli dhe rendesia e kontratave te adezionit, Prishtine,2004 faqe 12

${ }^{13}$ Kessler.D. Contracts of Adhesion--Some Thoughts about Freedom of Contract,1943 Colum. L. Rev. 629,632
} 
Legislators in some states have acted to limit freedom of contract for workers and employees by extending "right-to-work" laws to the public-sector. Recent political disputes in Ohio, Wisconsin, Indiana and Michigan, for example, have centred on restrictions to bargaining rights and union activities in the public sector.

There is tendency of the states, especially in USA, to approve "right-to-work" laws that clearly limit the freedom of contract for public-sector workers. In six of these states (Arizona, Idaho, Kansas, Nevada, Utah, and Virginia), public employees are included in the general "right-to-work" statute that applies to all workers and employers in the state. Kansas and Nevada also have additional "right-to-work" laws that specifically cover public workers. Nine states (Arkansas, Florida, Kansas, Michigan, Nebraska, Nevada, North Dakota, Oklahoma, and South Dakota) have general public employees "right-to- work" laws. ${ }^{14}$

Louisiana and Mississippi have "right-to-work" statutes specifically covering private-sector workers and employers, but does not specify whether public-sector contracts are also restricted under the law. Louisiana allows public-sector collective bargaining through case-law. ${ }^{15}$ In Mississippi, only case law Barriers to Freedom of Contract in the Public Sector addresses public sector collective bargaining. ${ }^{16}$ Referring to state statues and case law by the Association of American Educators ${ }^{17}$ and the Public Service Research Foundation ${ }^{18}$, Louisiana, Mississippi, and Wyoming have versions of "right-to-work" laws that apply to public-sector teachers. ${ }^{19}$ The legality of freedom of contract for other public sector workers is unclear in these four states.

\section{Application of labor contract and guaranteed instruments}

Due to the rapid development of the economy, aspiration and the tendency to speed up economic transactions, labor contract play a crucial role in the development of the new economic and legal relations. Despite this, the inequality encountered in this type of contracts, raises many issues for resolution.

The principle of contractual freedom must be analyzed in two ways. On the one hand, it is clear that the receiving party which stands in an inferior position in the market cannot negotiate about the terms of the contract. For this reason, the principle of contractual freedom is not applicable in the case of standard contract terms. On the other hand, where there are other economic operators who provide the same

\footnotetext{
${ }^{14}$ Milla Sanes, Barriers to Freedom of Contract in the Public Sector, November 2014, pp 2

${ }^{15}$ Case Law: Davis v. Henry, 555 So.2d 457, 459, 133 L.R.R.M. (BNA) 2271 (La., 1990)

${ }^{16}$ Case Law: Jackson v Hazelhurst, 427 So.2d 134, 137 (Miss. 1983)

${ }^{17}$ Association of American Educators and National Right to Work Legal Defense Foundation. "Forced Unionism: What You Should Know." Association of American Educators. http://aaeteachers.org/index.php/your-rights

${ }^{18}$ Public Service Research Foundation. "Teachers, Unions and Professional Alternatives: A question of choice." http://www.psrf.org/issues/teachers.jsp

${ }^{19}$ Milla Sanes, Barriers to Freedom of Contract in the Public Sector, November 2014, pp 4
} 
service, the recipient can choose contract terms more favorable but still through a limited negotiation process.

Legally speaking, the contractual freedom is very restricted in cases when the bidders are subject to monopolistic or oligopolistic position and there is lack of respect for the principle of contractual freedom. One of the parties is not free to determine who they will enter into contractual relationships with. This party cannot determine the conditions of the contract through negotiations with the other party. In this case the receiver is in an inferior position in relation to the bidder who operates in the privileged position. In spite of the legal instruments for the protection of the employees, the freedom of will principle is not respected especially is states with high unemployment rate.

\section{Conclusions}

Based on theoretical and practical approaches, it is shown clearly that when a commercial company operates as an exclusive service or goods supplier, the contracts with the employees will be adhesion contracts that will inevitably affect significantly the principle of contractual freedom. Freedom of contract and labour relations are closely intertwined. In labour relations, freedom of contract implies the freedom to conclude, formulate and terminate employment contracts. It is the result of developments throughout history that the parties to a labour relationship are not equal. As a rule, the employer has more economic advantages in conclusion of an employment contract. ${ }^{20}$ To balance the status of the parties to an employment contract, the Albanian government has imposed a number of restrictions to exclude employers' malpractice in exploiting labour. Despite the necessity to use the adhesion contracts as a practical and indispensable tool of modern economy, their disadvantages and flaws must be emphasized, in order to find the appropriate tools and mechanisms that will avoid them. In spite of the legal instruments for the protection of the employees, the freedom of will principle is not respected especially is states with high unemployment rate.

\section{Bibliography:}

- Richard Stone, The Modern Law of Contract, 5th ed.(2002) Cavendish Publishing,

- Pound, Liberty of Contract (1909), Yale L.J.; Williston, Freedom of Contract (1921), Cornel.L

- L. Q. 365;

- Hamilton, Freedom of Contract, ENcvc. Soc. Scr. 450, cited by: Kessler, Friedrich, Contracts of Adhesion-Some Thoughts About Freedom of Contract (1943). Faculty Scholarship Series. Paper 2731,.

- Duncan, N. Adhesion Contracts: A Twentieth Century Problem for a Nineteenth Century Code. 34 La. L. Rev.1974

${ }^{20}$ Gaabriel Tavits, Freedom of Contract in Labour Relations, JURIDICA INTERNATIONAL IV/1999, p188 
- Kessler, Fr. Contracts of Adhesion-Some Thoughts About Freedom of Contract. Faculty Scholarship Series., 1943,

- Hetemi.M, Detyrimet dhe kontratat,Tirane,Luarasi,

- Nicholas S. Wilson, Freedom of Contract and Adhesion Contracts, The International and Comparative Law Quarterly, Vol. 14, No. 1 (Jan., 1965), pp.172-193, Cambridge University Press on behalf of the British Institute of International and Comparative Law, P.172 note 4.Stable URL: https://www.jstor.org/stable/756723Accessed: 04-02-2020 13:08 UTC

- FUMSTON, CHESHIRE \& FIFOOT'S LAW OF CONTRACT, 9th ed. (1976) Butterworths P.23

- MICHAEL A. YANOU, LABOUR LAW PRINCIPLES AND PRACTICE IN CAMEROON, P.2 (2009) REDEF

- RICHARD STONE, THE MODERN LAW OF CONTRACT, 5th ed.(2002) Cavendish Publishing, P.2

- GAABRIEL TAVITS, "FREEDOM OF CONTRACT IN LABOUR RELATIONS", Juridica International IV/1999, 179-188, 180

- John S. Brubaker, A Realistic Critique of Freedom of Contract in Labor Law Negotiations: Creating More Optimal and Just Outcomes, 5 Wash. U. Jur. Rev. 107 (2012).P. 110-111, Available at: http://openscholarship.wustl.edu/law_jurisprudence/vol5/iss 1/3

- Trading Economics at http://tradingecoomics.com/cameroon/unemplyment-rate. Accessed on $03 / 03 / 2020$

- DAVID N. MAYER, LIBERTY TO CONTRACT: REDISCOVERING A LOST CONSTITUTIONAL RIGHT 1-10 (2011) (arguing for a return to the "Lochner era" of American constitutional law and the return of the fundamental right to contract)

- Anthony R. Chase, Race, Culture, and Contract Law: From the Cottonfield to the Courtroom, 28 CONN. L. REv. 1 (1995) (discussing the inability for slaves to contract).

- Yale Human Rights and Development Law Journal, Vol. 16 [2013], Iss. 1, Art. 2

- Nicholas S. Wilson, Freedom of Contract and Adhesion Contracts, The International and Comparative Law Quarterly, Vol. 14, No. 1 (Jan., 1965), pp.173

- Milla Sanes, Barriers to Freedom of Contract in the Public Sector, November 2014

- Case Law: Davis v. Henry, 555 So.2d 457, 459, 133 L.R.R.M. (BNA) 2271 (La., 1990)

- Case Law: Jackson v Hazelhurst, 427 So.2d 134, 137 (Miss. 1983)

- Association of American Educators and National Right to Work Legal Defense Foundation. "Forced Unionism: What You Should Know." Association of American Educators. http://aaeteachers.org/index.php/your-rights

- Public Service Research Foundation. "Teachers, Unions and Professional Alternatives: A question of choice." http://www.psrf.org/issues/teachers.jsp

- Gaabriel Tavits, Freedom of Contract in Labour Relations, JURIDICA INTERNATIONAL IV/1999, p188 